\title{
The Discourse of Sibling Violence
}

\author{
Heather Hensman Kettrey • Beth C. Emery
}

Published online: 16 August 2007

(C) Springer Science + Business Media, LLC 2007

In the publication of "The Discourse of Sibling Violence" (DOI: $10.1007 / \mathrm{s} 10896-006-9036-0)$ the $n$ value for the Level of Violence (L) - Severe cell in Table 3 was erroneously stated. The correct value is Severe $(n=138)$.

The online version of the original article can be found at http://dx.doi. org/10.1007/s10896-006-9036-0.

H. H. Kettrey • B. C. Emery $(\bowtie)$

Department of Human Sciences,

Middle Tennessee State University,

Box 86, Murfreesboro, TN 37132, USA

e-mail: bemery@mtsu.edu 